\title{
Trinity and mission: challenges to a reformed witness in Africa today ${ }^{1}$
}

\author{
Rian Venter ${ }^{2}$ \\ (Justo Mwale Theological College)
}

\section{ABSTRACT}

\section{Trinity and mission: Challenges to a reformed witness in Africa today}

The paper explores the possibility of a Reformed missional response to the present moment in Southern Africa. The basic thesis is that two of the Reformed tenets - theo-centrism and intellectual reflection as part of a holistic vocation - are especially suitable for a missional response, but stand in need of radicalising. The renaissance of trinitarian thinking and the ramifications for missiology and ecclesiology are discussed. Finally attention is given to quality improvement of theological school and the articulation of a comprehensive Reformed theology for Africa. The conviction is that these emphases will simultaneously be a turn to the material world and its challenges.

The present moment in Southern Africa is unique in its opportunity, its complexity, and its crisis. That something substantially new is taking shape is apparent. The dawn of inclusive democracy, the emergence of the African church as "the standard Christianity of the present age" (Walls 2002:119), the compression of the world through globalization (see Schreiter 1997), the crystallization of post-modernity as "the face of the other" (Tracy 1994:105) - all signal in its own way an aspect of this newness. Coupling this with deepening levels of poverty ${ }^{3}$ and continued racism $^{4}$, one starts to realize the challenge of our time. How are Reformed Churches to respond missionally? Do they have the potential to respond in any

1 Paper originally delivered at a conference on Mission and Reformed Churches in Southern Africa. Stellenbosch May 13, 2004.

2 Justo Mwale Theological College. Lusaka, Zambia.

3 One recent statistic suggests there is a 91\% increase in the number of people living on less than $\$ 1$ a day in Sub-Saharan Africa since 1981. See Time 3 May 2004, p14.

4 The psychologist $\mathrm{N}$ Chabani Manganyi refers to the denial of racism as the "family secret": we keep it in the closet. See Andersson (2004:16f). 
way? This paper will explore two unfashionable avenues: the doctrine of the trinity and theological education. What may seem to many as an esoteric and elitist escape may be a constructive way of theological engagement with the specific moment in Southern Africa. Both are Reformed tenets; if radicalized they may contribute to the vitality of the Reformed witness.

The proposal is offered with an acute sense of the risk of speaking in Southern Africa. Who speaks on behalf of whom and to what effect? Being a white South African male who has been living in Zambia for more than sixteen years, I am fully aware of being displaced and being an outsider. My speaking is perspectival and tentative (see Schipper 1994 on the issue of "insiders" and "outsiders, and who may speak). May be, my only claim will be to what Said (1994:47) refers to as "the audacity of daring."

\section{REFORMED IDENTITY}

\subsection{Diversity and a Minimalist Approach}

The question arises whether it is necessary at all to join the old game of identifying what it means to be Reformed, prior to a treatment of the challenges. Has this method of proceeding not become suspect? Deductive thinking precludes possibilities for creating new answers. Should we first know who we are before we identify our responses? In one sense the answer is obviously no; in another it may be yes. History may suggest that Reformed Churches have embodied a certain ethos, exercised a certain reflex, because of express and conscious convictions concerning their uniqueness. My own approach, which will gradually crystallize, is more inter-actional, more that of a spiral: certain identity features may deliver a specific way of addressing challenges, but these challenges may also stimulate the tradition to evolve.

What then is "Reformed"? The moment one is confronted with the task to articulate, a strange irony becomes manifest: the very people whose self-understanding is resolutely Reformed, display a strange inability to capture that identity in a uniform and quite satisfactory way. No wonder that Brinkman (1995) titles one of his articles on this issue "Onwil en Onmacht tot het Formuleren van een Gereformeerde Identiteit". A quick glance at attempts to give expression to the identity of the Reformed tradition (see e.g. Burger 2001, Christian Reformed Church in North America 2003, Jonker 1994, Klooster 1979, Torrance 2000 and Vroom 2000) seems to 
justify Brinkman's unwillingness and even inability to formulate this. The customary neglect of giving an account of the methodology of description, the complex character of any tradition itself and the nature of any re-presentation may offer explanations for these diverse profiles.

Identity and tradition are multi-dimensional realities and any venture at description should methodologically accommodate that. Any religious tradition has the following dimensions: a certain history and historical development, a certain doctrinal system, a certain ethos (behaviour and attitudes of a group of people), a certain spirituality (including public worship), certain rituals and a certain social organization of the group. The tendency among Reformed scholars is to give such emphasis to the doctrinal aspect, that other elements are neglected. People belonging to a Christian tradition see life and the world in a specific way, they relate to others, to the world and nature in their own way, they value certain things, they worship in a distinctive manner and they organize themselves differently. The dimensions that Smart (1996) identifies in religions may be meaningfully applied here to the treatment of different Christian traditions. He mentions the ritual or practical -, the doctrinal or philosophical -, the mythological or narrative -, the experiential or emotional -, the ethical or legal -, the social or organisational -, and the material or artistic dimension. One dimension should be added to Smart's that is often neglected: the metaphorical language unique to each tradition. Ultimately language shapes experience and a symbolic universe. To stress the methodological question, is to acknowledge the complex and comprehensive nature of mapping the character of any religious tradition. The attempt by Leith (1977), although a bit dated and not particularly thorough, remains a benchmark in this regard.

A second perspective is important here. Describing the identity of the Reformed tradition is fundamentally an imaginative and constructivist activity. Often the danger of an essentialist approach lurks in the background, meaning that Reformed identity is understood as something static and objectively out there in pure form that can be captured and correctly re-presented by reflection. Being Reformed is a lived reality which configures the various dimensions mentioned. Describing the identity of the Reformed tradition is a subjective project which reflects the scholar's own reading of dimensions as actually manifested. 
For the purpose of this paper I will follow a minimalist approach that I believe should not be contentious. I propose that Reformed faith as lived ecclesial reality has been, and still is, fundamentally determined by the conviction that

- God is sovereign and central

- the Bible as mediation of his Word is the authoritative source and norm for all of life

- Grace fundamentally characterizes life as such, as well as the God-human relationship

- Creation and recreation are juxtaposed in such a way to enable an appreciation for the entire life

- Christian vocation embraces worship, study and service

The symbolic world created by this theological vision is radically theo-centric, non-dualistic, dynamic and gracious.

\subsection{Unsettling Paradoxes}

The moment one tries to profile some constituent structures, two quite unsettling realities inevitably impose themselves upon one: the relation of this tradition to Apartheid and its potential to answer the deepest existential needs of the African person. If the symbolic world created by these Reformed tenets appears to be so lifefriendly, why could it not resist Apartheid as a visitor totally unwelcome within its accommodational space? Put in other words: what in this particular theological interpretation and embodiment of the Christian faith allowed for oppression and discrimination? Does it harbour a treacherous Achilles heel? Secondly, why does it seem that despite the appreciation for the "richness" of its theology, there appears to be "somehow a problem" in Africa? When an atmosphere is created for open discourse, certain themes continue recurring about African realities not fundamentally and satisfactorily addressed by the Reformed tradition: death and funerals, witchcraft, marriage and childbearing, and social suffering (interview Banda, Banda \& Zulu. 2004). It appears that the role of the church needs to be complemented with some traditional African element at funerals, that the church does not provide "a remedy" for torment by witchcraft, that the church is oblivious to the importance of having a descendent to "carry one's name on" and that the Reformed faith "helps to endure suffering in stead of changing society". 
There is nothing particularly new in identifying these two sets of problems. The theological agenda of Reformed theology in a Post-Apartheid Africa will be haunted by these questions. It will require a detailed exposition of the tradition's apparent weaknesses, and the underlying dynamics; but even more it will require an exploration of the tradition's potential to reinvent itself along the very lines identified in the "minimalist pillars". The venture to sketch the contours of a tradition's identity is never an exercise aimed at self-indulgence, but rather at honest self-reflection for personal and social relevance.

\subsection{One Nagging Suspicion}

Despite my appreciation of the Reformed tradition, I cannot suppress my suspicion that there is more than the meets eye on the surface. Especially one such suspicious area should be voiced that I believe has also some direct bearing on the missional task. Is the claim of theo-centrism a mere formal rhetorical strategy to discredit alternative views as anthropocentric, or is it really the material optic of the entire theological vision? More substantially: what is the actual material content of the so-called theo-centric perspective? Is it consistently trinitarian, or does a generic (read: Hellenistically influenced) conception lurk somewhere in the background? What is the possible interface between the Reformed understanding of God and the legitimization of Apartheid? The central image of God has massive impact on individual lives but also on social dispensations. Ultimately, the vitality of a religious tradition is dependent on this central symbol: its imagination of the Sacred, of God. This issue and these questions will lead to the crux of the thesis pursued in this paper.

\subsection{One Unsung Strength}

It is not particularly fashionable to offer an apology for intellectual work, for advanced theological reflection amidst personal or social exigencies. It is pitted in dichotomous manner as escaping action, as stifling piety. Attention should be called to the Reformed tradition's appreciation for rigorous theological reflection, for quality theological education. What is often disparagingly labelled its cerebral inclination, may actually turn out to be a unique strength. I believe this very feature of the Reformed tradition should be employed in the quest for a missional approach in a new era. 


\section{BASIC PROPOSAL}

Space permitting, the most appropriate way would have been to explore a variety of typically Reformed features and relate them to mission and to Africa. In this paper the basic thesis is that two of the Reformed tenets - theo-centrism and intellectual reflection as part of a holistic vocation - are especially suitable to enable the church to respond missionally to the present moment in Africa. Without denying other options, these could be most productive possibilities to explore. Both stand in need of radicalising: theo-centrism as trinitarianism, and theology as quality improvement of theological school and articulation of a comprehensive Reformed theology for Africa. The conviction is that these emphases will simultaneously be a turn to the material world and its challenges.

\section{THE TRINITARIAN TURN, MISSION AND AFRICA}

\subsection{Trinitarian Renaissance}

To argue for a radicalizing of the Reformed theo-centric tenet, in terms of consistent trinitarianism, is not to imply that God was viewed merely mono-theistically in the past. The trinitarian confession has always been the criterion for orthodoxy, it has always framed our liturgical service. The question, however, is: does the confession of God as a triune God, fully orientate and inform our theology, our understanding of ourselves, our world, our vocation, our spirituality? Or have we in practice forgotten it?

The retrieval of the importance of the trinity has been one of the outstanding achievements of theology in the twentieth century. The impact of Barth in this regard is widely acknowledged. By placing the question of the triune identity of the God who reveals himself prominently at the beginning of Dogmatics, inaugurated a turn in theology that is still being explored. The comment by Barth (1975:303) in this regard is significant: "In giving this doctrine a place of prominence our concern cannot be merely that it have this place externally but rather that its content be decisive and controlling for the whole of dogmatics." The notion of a "trinitarian renaissance" is widely used to indicate this significant shift in theology (for good overviews see Grenz 2004 and Thompson 1997). To convey the myriad perspectives generated by contemporary trinitarian theologians is an impossible task within the purview of this paper. The following may be highlighted: The trinity is the Christian way of speaking about the identity of God. It is not a 
doctrine of secondary importance "in addition to some other basic concept of the one God" (Pannenberg 1991:530). The biblical narrative of God and his people "is true of and for God himself" (Jenson 1995:42). As three Persons - Father, Son and Spirit - from all eternity, in his own being, God is relational; LaCugna (1991:243) summarises the crux of the contemporary emphasis: "trinitarian theology is par excellence a theology of relationship." The trinitarian doctrine is expressly a practical doctrine: it is "about life, life before God, with one another and in the world" (Gunton 2003:11). Two significant developments are being undertaken: the full Christian vision is explored from the perspective of the trinity, e.g. the notions of a trinitarian anthropology, a trinitarian ecclesiology are becoming common; secondly, specific problems in society, like sexual discrimination and plurality, are approached in trinitarian light.

To my mind the significance of this development can in no way be devalued. To do the-ology, is to view life in the light of God; if this God's identity is triune, a consistently trinitarian theology becomes inevitable, it becomes our task. To the Reformed mind this does not sound particularly foreign. To stress the biblical salvific narrative is to recall the work of a specific God who meets us as Father, Son and Spirit. Calvin himself is well-known to be an outstanding trinitarian thinker (see Butin 1995). The question, however, is: how consciously, how consistently trinitarian are we in theological and ecclesial practice? Placher's indictment (1996) of "domesticating" God may be applicable to us.

My suggestion, and one of the basic theses of this paper, is that we should radicalize our own basic identity-maker, that is, being theo-entric. Our Reformed trinitarian confession should fully inform our understanding of (a) the Missio Dei, (b) our ecclesiology, and finally (c) the outstanding exigencies of our context - poverty and relationships. These will be briefly explained.

\subsection{Missio Trinitatis}

The notion of mission as fundamentally God's work, Missio Dei, in which the church is privileged to participate has become a missiological axiom (see Bosch 1991:389-393; see also the issue of International Review of Mission 2003/92 [367] which focuses on the Willigen Conference and the Missio Dei). The question could be raised whether there is not a need to speak consistently of Missio 
Trinitatis. That mission is the work of the Father, the Son and the Spirit has been from the beginning of its articulation the underlying assumption. The history of the effect of the term discloses, however, some ambiguity: it has expanded the scope of mission, but simultaneously relativized the importance of the church, especially with reference to the existence of other religions. A thorough rethinking of the Missio Dei as explicitly Missio Trinitatis may be overdue. The God in whose service the church stands has a specific identity-narrative. The employment of insights, and especially of Patristic and contemporary trinitarian theology, more consciously, may bring greater clarity to some of the problems created by the category. One can easily identify with Richebächer's (2003:599) sentiment: "By using trinitarian theological interpretations more precisely, the missio Dei expression does have a real contribution to make to updating the explanation of Christian mission today". One such insight is clearly detectable in the literature: greater insistence on the unity of the triune God's work (see e.g. Matthey 2003:581f and Engelsviken 2003:493). For Reformed theology this trinitarian deepening of the concept is imperative; for example, the Spirit has always been closely connected by Christ's work.

One possible way to explore the significance of Missio Dei as Missio Trinitatis, is to point to the nature of the very life of the triune God, life that is characterized by fecundity, ec-stasis (this refers to going outside and beyond the boundaries of the "self"; Zizioulas (1994:359) contends that this is a movement of "affirmation of the other"), self-communication, mutuality, relationship. The God whose mission is at stake is a God of love, of communion. Mission is extending an invitation to enter a specific new world, a trinitarian space, where the God of communion extends his hospitability. Mission has to do with the church's mediation and enactment of this communion. Mission is the ec-static movement of the church towards the world; as ec-static community it becomes missional itself. The trinitarian space mediated by the church, entails God's self-gifting, God's all-embracing care.

A full exposition of the Missio Dei along trinitarian lines, is a future task still to be undertaken. This may generate a new metaphoric vocabulary, but also on much deeper level, a trinitarian ontology, an understanding of reality in light of relationality and communion. 


\subsection{Trinitarian Ecclesiology}

What does this imply for understanding the nature of the church? This question flows virtually inevitably from the previous perspectives. If the church participates in the mission of the triune God, what is "church" then? Some form of connection between church and trinity seems obvious. According to Gunton (1997:56) this has exactly been the inadequacy of ecclesiology: "it has never seriously and consistently been rooted in a conception of the being of God as triune". Volf (1998:191) articulates the state of an emerging ecclesiological paradigm: "the thesis that ecclesial communion should correspondent to trinitarian communion enjoys the status of an almost self-evident proposition". The keywords to take note of are "correspondence" and "communion". Although the radical distinctiveness between God and church is fully recognized, the issue at stake is the quest for an appropriate ontology of the church, which is identified as a form of correspondence between the triune God as communion and the church as communion. Gunton (1997:71) contends: "the sole ontological basis for the church is the being of God". Jenson (1999:173) puts the matter somewhat differently, but with the same conclusion: the needed "social theory" for understanding the nature of the church "is and can only be the doctrine of the Trinity itself". The basis for the correspondence is usually found in baptism as initiation into new identity and in the imago Dei motif. Speaking about the church in trinitarian light is analogous talk, which allows for new possibilities of understanding, but also admits the limits of such correspondence (especially Volf 1998:191-220 displays sensitivity for the limits of the analogy).

At the centre of a trinitarian ecclesiology is an understanding of church as community (see Migliore 2003). The identity of the church as community emerges out of the identity of the God it serves. In such an understanding of church the notion of relationality is paramount. The members who are equal, live from and toward others. It is a space of love where relations are mutual and reciprocal; above all, unity is valued. As "echo" of the triune God, the church is ec-static: it does not live for itself, but for the world. Strikingly Grenz (2003:264) refers to the church as "a community missionally marked".

The implications of this for ecclesial practice are vast. So many relational matters in the church could be viewed differently. For example, the question of authority and power, which is often an 
issue between ministers and elders, becomes immaterial in light of a trinitarian approach to church polity (see Fiddes 2000, especially chapter 3 on "The Triune God and the Questions of Power and Authority"). Closer to the focus of the workshop: the future of relations among Reformed Churches in Southern Africa can be positively informed by a trinitarian approach. Volf's notion (1998:216) of "symmetrical reciprocity" which characterizes the intra-trinitarian relations, can be most helpful to think of the relationship between the various Reformed Churches. There should be mutuality, which is not strained by any form of imbalance, for example, financial. The trinitarian notion of perichoresis (see Harrison 1991 for its original Patristic meanings) that refers to the unity of the divine persons in their mutual interpretration, is often transferred to human and ecclesial relations. Although a contentious methodological move (see Otto 2001 for the use and abuse in recent theology) it remains - heuristically - helpful to envision distinctiveness and yet, simultaneously, most intimate unity. If our relations could be truly perichoretic, we could be a sign to the world of the new life offered by the Father in Christ through the Spirit.

\subsection{The Trinitarian Turn as Turn to the World}

It would be a grave mistake to assume that a trinitarian turn amounts to a flight from the world and its concrete problems. Exactly the opposite is true: the trinity is "a public truth" (Newbigin 1997:1) and "ultimately a practical doctrine with radical consequences for Christian life" (LaCugna 1991:1) Doing trinitarian theology means being engaged with life. It is a refusal to abdicate thinking about and addressing social exigencies to mere pragmatism or to moralism with its domesticated generic theology. It is taking the Christian God ánd life seriously.

Trinitarian theology resonates in a unique and surprising way with the basic orientation of the Reformed faith, with post-modern sensibilities (Cunningham 2003:186-202 treats this incisively), and with the communitarian cosmology of Africa (see Ogbonnaya $1994)^{5}$. It offers resources to think - theologically - about urgent

5 The most consistently trinitarian thinker in Africa theology is arguable the Roman Catholic Charles Nyamiti. Many of his articles are to be found in the African Christian Studies journal. He relates the trinity to issues like marriage, family, sexual ethics, ancestor veneration, naming ceremonies and responsibility. 
social challenges in Southern Africa like poverty and relationships. In doing trinitarian theology it may be helpful to point out two methodological nuances. "God" can refer to a Living Divine Agent who acts, to a Divine person to whom we relate, but also - and this is quite crucial for trinitarian thinking - to a Divine Model for humans who discloses ultimate truth. To illustrate the last reference: what personhood, otherness, unity, relationship, community ultimately should be, are revealed by the triune identity of God. Secondly, God radically affects life with His action; but when speaking about God we as humans also affect life with the very images we employ to convey God's mystery. God-images have deep impact. The way we speak about God, when reflecting about mission, is powerful!

Two brief illustrations, relating to two of our most serious challenges - poverty and relations - can be offered to indicate the heuristic potential of trinitarian thinking for Southern Africa, and for a contemporary missional approach.

To approach poverty is to identify two forms of logic at work. For the following insights I am fully dependent on the work by Meeks (1980 \& 1996); his larger work (1989) is extremely important. The nature of our human society is based on the accumulation of wealth as power, and the logic is that of exchange. The economic ethos is characterized by possessive individualism, compulsion to consumption and a sense of scarcity. The trinity opens the possibility of thinking about God's being as self-giving love, as gifting $^{6}$. Downey $(2000: 43,48)$ views the doctrine of the trinity as a "grammar of gift": "God is inexhaustible Gift, Given and Gift/ing in and through love". This creates an entire new vision: instead of a commodity society, we find the church as gifting community. Exchange is replaced by a reciprocity or mutuality of giving. The generosity of God opens the possibility for an economy of life, with abundance in the Spirit instead of scarcity. This requires an entire new way of re-envisioning life. Webb (1996:152) makes the perceptive remark: "The languages of giving, justice, and grace are one and the same". To respond to dehumanizing poverty, the church needs to speak an alternative word that invalidates a total strategy to

6 The debate between Marion and Derrida on "Gift" is exceedingly relevant for trinitarian thinking and for offering a specific Christian response to poverty. For this debate see Horner (2001). 
life. Radicalizing the Reformational word of grace may be dangerous and puts us into uncharted waters!

Relational matters have become arguably the most painful and shameful arena where our failure as human beings is visible. Whether it entails races, cultures, sexes, or churches - our inability to cope with "otherness" is paramount. We marginalize, oppress, isolate, disparage, alienate; the vice-catalogue is endless. The history of Southern Africa is a living testimony to this. The trinitarian narrative of God's identity reveals how humans made in his image, should be. Human beings as persons are intrinsically relational; they are what they are by virtue of their relations to others; the definition by Vanhoozer (1997:176) of a person as "a communicative agent in a web of communicative relationships with others" is indicative of much recent thinking. Otherness and community belong inextricably together. We are part of a "perichoretic universe" (Gunton 1993:173), where our particular identity is constituted by our very relatedness in communion. Relationships are not supplementary to our being. Gunton (1993:194) is emphatic that being and relation "stand or fall together"; says he: "It cannot be stressed too strongly that what we are concerned with here is a new kind of ontology, an ontology of communion" (1993:214 n 4). That relationality in trinitarian sense has a unique dimension: it is living from and for others; in short love. The implications of this for our lives in Southern Africa are obvious, as unsettling and disturbing as that may be.

One is hesitant to ponder the unavoidable question: what if...? What if Reformed the-ology and ecclesiology had been fully and consistently trinitarian in the past? Could the tragic history of Southern African be different?

\section{TRINITY, MISSION AND THEOLOGY}

The first response to the revelation of God's triune identity is spontaneous worship and celebration. Only that language can give expression to the Mystery that encounters us. To become engaged in this movement of love towards the world is a second reflex. The triune beauty of God invites also reflection, study, and imaginative interpretation of our world. It is specifically this answer to God's revelation that I would like to discuss briefly. 


\subsection{A Little Apology}

There is often the suspicion that intellectual work is an escape from life, irrelevant to the exigencies of the time. Theological talk about the trinity is sometimes ridiculed as esoteric gymnastics. My basic thesis is that theology belongs to our privileged participation in God's very mission itself. The ec-static movement of God towards the world in its fundamental narrative structure renders inscripturation virtually inevitable. God's encounters with his people had to be preserved. This shift, from oral memory to a written canon, made literacy, study and teaching imperative. The very nature of God's revelation forms the rationale for doing theology. Thinking trinitarianly about mission is to include theology. Theology is not something in addition to mission, it flows logically out of it. Secondly, the non-dualistic nature of the Reformed mind embraces all of human faculties as in service of the honour of God. Disparaging theology will contradict this very Reformed tenet. Thirdly, the complexity of the social and intellectual horizon of our lives in Southern African requires nothing less than rigorous academic work. For example, the depth of poverty cannot be dealt with by a few slogans. Finally, the rational spaces opened up by education are all subject to interests, values and concerns and elicit ethical effects. In short, bad theology leads to bad ecclesial practice. Our very historical moment requires solid academic theological work.

\subsection{Back to Basics}

This plea does not entail the creation of another from of unreformed hierarchy: the privileged intelligentsia and the African illiterate. On the contrary, disturbing levels of illiteracy, lack of Bibles, surprising ignorance of basic Bible content, lack of Christian literature should be addressed as priorities. A strategic approach to mission in Southern Africa, will embark on imaginative three or five year projects in this regard. The need for dynamic and holistic Christian education programmes cannot be overstated.

\subsection{Centers of Empowerment}

The existence of a network of Reformed theological institutions in Southern Africa attests to the appreciation of education in this tradition. This is an achievement to be recognized. The potential of these institutions to be centres of human empowerment to cope with life, to edify the church, to fulfil the missional call is obvious. The 
dilemmas besetting the same institutions, specifically those not attached to a university, are however daunting: inadequate physical infra-structure, severe budgetary constraints, insufficiently trained faculty, unsatisfactory library holdings. To this somewhat depressing picture two additional features should be added: disproportionate faculty representation by men and women, and disparity among churches concerning duration and quality of training. Any reflection about the future of Reformed mission in Southern Africa, and the allocation of limited resources, can hardly bypass these institutions and their crucial contribution. The challenge will be to strategically develop these institutions as missionally-oriented centres with emphasis on relevance, quality, sustainability and inclusivity. The curricula will obviously be the arena where these values fail or succeed. Strategic diversification of programmes to serve a spectrum of target groups will have not be carefully considered, as well as the introduction of non-traditional course like Economics and Development Studies. Radicalizing this basic Reformed tenet implies concentrating on developing these institutions resolutely.

\subsection{The Elusive Dream: A Reformed Theology for Southern Africa}

The lack of suitable textbooks acutely epitomizes the need for a comprehensive Reformed theology for Southern Africa. The vitality of Reformed churches will ultimately depend on an articulated theological vision which respects the truth of God's triune identity, the richness of the Bible, the basic perspectives of the Reformed tradition, the validity of the African religious heritage, experiences of conflict and suffering, and the hope for a substantially different future. A mere repetition of traditionally formulated doctrinal positions, or the occasional and fragmentary treatment of a topic "from an African perspective" will not suffice. The need is clearly for a coherent and comprehensive articulation. Theological visions create space for living, for making decisions, for relating to others; in short, it impacts people's lives. A new historical moment renders this task more urgent and imperative than ever before. It will require courage and creativity to speak within Dogmatics about a theology of poverty, a theology of the body, a theology of social forgiveness, a theology of rites of passage. Arguably, more than anything else, we will have to speak about why things happen, and who or what causes them. This is central in African thinking; see e.g. concerning illness, Kasambala (2004:97-100). A thorough theology of causality, 
informed by the African cosmology, by modern and post-modern perspectives, and finally by the ultimacy of the triune God may immeasurably address deep existential needs. If faith in the triune God, and the corresponding world it creates, cannot liberate people, cannot motivate people to social engagement then some deep theological conundrum exists. Equally, a theology of power and celebration, is overdue. For too long have we retreated from speaking openly and bravely about the Holy Spirit. The African experience demands a bold expression of the empowering work of the Spirit.

No fixed canon of answers exists. Education as transfer of knowledge has long ago been discredited. Knowledge should be constructed as we go along. Lecturers will have to learn as much as students. Our aim will have to be to facilitate and foster a certain approach to life. If students and lecturers could learn to think "trinitarianly" theology will become mission. This will place God central in theological education and orientate it towards mission (see Kelsey 1992 and Banks 1999).

This is an exciting time for theologizing: to listen to suppressed voices, to explore new themes. It is essentially a time of opportunity: to enrich the interpretation of the Reformed faith from within Africa, with new questions, new sensibilities. If this could materialize an African contribution could be made to the global church. This is theology in trinitarian light: excess in reciprocity!

\section{CONCLUSION}

If Reformed mission in Southern Africa could be radically informed by God's triune identity and be supported by radically improved theological education it may be positioned to make a unique contribution to Southern Africa.

\section{Consulted literature}

Andersson, M 2004. Dreaming of a new kind of freedom. Mail \& Guardian 30 Apr-6 May, 16-18.

Banks, R 1999. Reenvisioning Theological Education: Exploring a Missional Alternative to Current Models. Grand Rapids: Eerdmans.

Barth, K 1975. Church Dogmatics 1/1: The Doctrine of the Word of God. Edinburgh: T \& T Clark.

Bosch, D J 1991. Transforming Mission: Paradigm Shifts in Theology of Mission. Maryknoll, NY: Orbis. 
Brinkman, M E 1995. Onwil en Onmacht tot het Formuleren van een Gereformeerde Identiteit. Gereformeerd Theologisch Tijdschrift 95, 59-68.

Burger, C 2001. Ons weet aan wie ons behoort: Nuut gedink oor ons gereformeerde tradisie. Wellington: Lux Verbi. BM.

Butin, P W 1995. Revelation, Redemption \& Response: Calvin's Trinitarian Understanding of the Divine-Human Relationship. Oxford: Oxford University Press.

Christian Reformed Church in North America. 2003. What it Means to be Reformed: An Identity Statement. REC Focus 3(2), 71-98.

Cunningham, D S 2003. The Trinity, in Vanhoozer 2003:186-202.

Downey, M 2000. Altogether Gift: A Trinitarian Spirituality. Maryknoll, NY: Orbis.

Engelsviken, T 2003. Missio Dei: The Understanding and Misunderstanding of a Theological Concept in European Churches and Missiology. International Review of Mission 92(367), 481-497.

Fiddes, P S 2000. Participating in God: A Pastoral Doctrine of the Trinity. Louisville: Westminster John Knox.

Grenz, S J 2003. Ecclesiology, in Vanhoozer 2003:252-268.

-, 2004. Rediscovering the Triune God: The Trinity in Contemporary Theology. Minneapolis: Fortress.

Gunton, C 1993. The One, the Three and the Many: God, creation and the culture of modernity. Cambridge: Cambridge University Press.

-, $1997^{2}$. The Promise of Trinitarian Theology. Edinburgh: T \& T Clark.

-, 2003. Father, Son \& Holy Spirit: Towards a fully trinitarian theology. London: T \& T Clark.

Harrison, V 1991. Perichoresis in the Greek Fathers. St Vladimir's Theological Quarterly 35, 53-65.

Horner, R 2001. Rethinking God as Gift: Marion, Derrida, and the Limits of Phenomenology. New York: Fordham University Press.

Jenson, R W 1995. What is the Point of Trinitarian Theology? In Schwöbel, C (ed). Trinitarian Theology Today, 31-43. Edinburgh: T \& T Clark.

-, 1999. Systematic Theology vol 2: The Works of God. Oxford: Oxford University Press.

Jonker, W D 1994. Bevrydende Waarheid: Die karakter van die gereformeerde belydenis. Wellington: Hugenote-Uitgewers.

Kasambala, A E 2004. The Interplay between God-Images and Healing in Pastoral Ministry: Engaging an African Spirituality. Stellenbosch: Unpublished D.Th. Dissertation.

Kelsey, D H 1992. To Understand God Truly: What's Theological about a Theological School. Louisville: Westminster John Knox. 
Klooster, F H 1979. The Uniqueness of Reformed Theology. Calvin Theological Journal 14(1), 32-54.

LaCugna, C M 1991. God for Us: The trinity and christian life. San Francisco: Harper.

Leith, L H 1977 Introduction to the Reformed Tradition. Atlanta: John Knox.

Matthey, J 2003. God's Mission Today: Summary and Conclusions. International Review of Mission 92(367), 579-587.

Meeks, M D 1980. The Holy Spirit and Human Needs: Towards a Trinitarian View of Economics. Christianity and Crisis 40 (Nov 10), 307-315.

-, 1989. God the Economist: The Doctrine of God and Political Economy. Minneapolis: Fortress.

-, 1996. The Future of Theology in a Commodity Society, in Volf, M et al (eds). The Future of Theology: Essays in Honor of Jürgen Moltmann, 253266. Grand Rapids: Eerdmans.

Migliore, D L 2003. The Communion of the Triune God: Towards a Trinitarian Ecclesiology, in Alston, W A jr \& Welker, M (eds). Reformed Theology: Identity and Ecumenicity. 140-154. Grand Rapids: Eerdmans.

Newbigin, L 1997. The Trinity as Public Truth, in Vanhoozer, K J (ed). The Trinity in a Pluralistic Age, 1-8. Grand Rapids: Eerdmans.

Ogbonnaya, A O 1994. On Communitarian Divinity: An African Interpretation of the Trinity. New York: Paragon House.

Otto, R E 2001. The Use and Abuse of Perichoresis in Recent Theology. Scottish Journal of Theology 54(3), 366-384.

Pannenberg, W 1991. The Christian Vision of God: The new discussion on the trinitarian doctrine. Trinity Seminary Review 13, 53-60.

Placher, W C 1996. The Domestication of Transcendence: How modern thinking about God went wrong. Louisville: Westminster John Knox Press.

Richebächer, W 2003. Missio Dei: The Basis of Mission Theology or a Wrong Path? International Review of Mission 92(367), 588-605.

Said, E W 1994. Representations of the Intellectual. London: Vintage.

Schipper, M 1999. Imagining Insiders: Africa and the question of belonging. London: Cassell.

Schreiter, R J 1997. The New Catholicity: Theology between the Global and the Local. Maryknoll, NY: Orbis.

Smart, N 1996. Dimensions of the Sacred: An Anatomy of the World's Beliefs. London: HarperCollins.

Thompson, T R 1997. Trinitarianism Today: Doctrinal renaissance, ethical relevance, social redolence. Calvin Journal of Theology 32, 9-42.

Torrance, T F 2000. The Distinctive Character of the Reformed Tradition. Reformed Review 54, 5-16. 
Tracy, D 1994b. Theology and the Many Faces of Postmodernity. Theology Today 51(1), 104-114.

Vanhoozer, K J 1997. Human being, individual and social, in Gunton, C E (ed). The Cambridge Companion to Christian Doctrine, 158-188. Cambridge: Cambridge University Press.

Vanhoozer, K J (ed) 2003. The Cambridge Companion to Postmodern Theology. Cambridge: Cambridge University Press.

Volf, M 1998. After Our Likeness: The Church as the Image of the Trinity. Grand Rapids: Eerdmans.

Vroom, H M 2000. On Being "Reformed", in Lienemann-Perrin, C et al (eds). Reformed and Ecumenical, 153-169. Amsterdam: Rodopi.

Walls, A F 2002. The Cross-Cultural Process in Christian History. Maryknoll, NY: Orbis.

Webb, S H 1996. The Gifting God: A Trinitarian Ethics of Excess. Oxford: Oxford University Press.

Zizioulas, J 1994. Communion and Otherness. St Vladimir's Theological Quarterly 38, 347-361.

\section{Interview}

Banda, D A C, Banda D T \& Zulu, A G. May 6, 2004. Interview with author. Lusaka, Zambia. 